\title{
An Ethnographic Exploration of the Lyngam Ethnic Community in Bangladesh
}

\author{
Nur Mohammad Majumder ${ }^{1,2}$, Lye Tuck Po ${ }^{3}$, Sanjay Krishno Biswas, ${ }^{1, *}$ \\ ${ }^{1}$ Department of Anthropology, Shahjalal University of Science \& Technology, Bangladesh \\ ${ }^{2}$ University Sains Malaysia, Malaysia \\ ${ }^{3}$ Department of Anthropology \& Sociology, University Sains Malaysia, Malaysia
}

Copyright $(0)$ 2015Horizon Research Publishing All rights reserved.

\begin{abstract}
The Lyngam community is living over a hundred years as a distinct ethnic group maintaining racial and cultural identity at Kalmakanda Upazila of Netrokona district in Bangladesh. Generally, mainstream people are not aware of their culture. Yet the scholars and researchers did not study on their origin, history, and culture. A few anthropologists, sociologists and linguists examined the Lyngams culture and trend of cultural dynamics as part of Khasi and Garo (dominant tribes). This paper attempts to understand and describe how the way of life and culture of Lyngam is constructed to the context of self-image and other communities with Christianization. To explore the Lyngams' cultural traits, attributes, and existing trend, an ethnographic approach round a year and an in-depth interview method are employed here. These methods along with secondary information reveal that the Lyngams' way of life and cultural dynamics are the amalgamation of Khasi and Garo culture. The intermingled product of Khasi and Garo culture is treated as a separate ethnic group that could be considered as the Lyngam community.
\end{abstract}

Keywords Lyngams Community, Hybrid Culture, Christianization, Cultural Dynamics

\section{Introduction}

The Lyngams is a small ethnic minority living the northeast part (in Netrokona district) of Bangladesh. Most of the people of the country do not know much about them. Normally, Lyngam people are known as part of the major Khasi tribe. In fact the Lyngams are a specific group of people, both racially and culturally. The meaning of the word Lyngam is disputed. Lyngam is a Khasi name. The Garos call them Megams. Playfair calls them 'Nunia Garos'. Some scholars $[6,13,4]$ consider the word 'Lyngam' as 'we are men'. The Lyngam oldest folksong tells them as 'Kon Blei' (children of God). The Lyngams may denote another word 'maram' which signifies something that is clammy. Normally, the Khasi community is composed of five sectsKhasi, Synteng, War, Bhoi and Amwi [1]. Among these sects there are no Amwi people in Bangladesh.

The largest Lyngams community lives in the western part of the Khasi hill in Meghalaya in India. Their area extends from Boko to Bangladesh. They are supposed to have Garo origins, but have inclination to Khasi customs. In fact the origin of the Lyngam people is shrouded in obscurity. The Lyngams speak dialect of their own. A few existing tradition indicates that the Lyangams are considered as a non-Khasi people. Some scholars consider that they may be a hybrid group and intermixture of Garo-Khasi in the Lyngam area [1]. Ethnically Lyngams could not be called pure Khasi; nor are they Garo. Though, they live in Khasi hills, they are different from the Khasis in language, customs and the way of life. The Lyangams may be identified with the Khasis. They dislike being called like Garos.

In physical features Lyngams look more similar to Garos than Khasi. A good number of Garos live in west Khasi hills and they have been living with the Lyngams from time immemorial are called them the migmams. The earliest deeds on the Lyngams [6] indicate that they look as a Khasi sub-tribe. Anthropologists, sociologists and linguists are not fully agreed on ethnic identity of the Lyngams. They are neither pure Khasis nor pure Garos [10]. Some scholars [7] show that the Lyngams to be a very special group. The Lyngams are a separate division, being half Khasi and half Garo. Although, they are considered Khasi, marked differences, exist between them and their neighbours, the Garos, in physical traits, dress, customs and their dialects. The Lyngams physical structures and linguistic peculiarities show that they are an Austro-Asiatic Mon-Khmer speaking indigenous people.

Battacharjee [2] and Sangma [15] suggest that the Lyangams are one of the sub-divisions of the Garos (Achik). Some scholars of NEHU (North Eastern Hill University, India) note that the Lyngams differ not only from most of the Khasi sub-populations but from the Garo also. Scholars 
could not venture to arrive at any definite conclusion. But possibly suggest that the Lyngams seem to be a distinctly different population and with all probability not either a sub-population of the Khasi or of the Garo. Hellen Giri, lecturer of NHEU says, "Tradition tells that the Khasis, whether Bhoi, Khynriem, Lyngam, Maram, Pnar, Synteng and War etc. belong to one race (Khasi)." Lyngdoh [9] states that the Khasi includes all the Khasis - Bhoi, Khynriem, Maram, Pnar, Synteng and War those are residing in the Khasi hills and some of them are residing outside the hills, the plain land areas of Bangladesh.

\section{Methodology}

This study is carried out in villages - Jagirpara, Bangkona, Panchgaon, Patlaban and Dippur - at Kalmakanda Upazila of Netrokona district, where the Lyngam community lives and maintains their ethnic and cultural identity. Researcher gathered information over a year from 2012 to 2013. The field study was conducted through ethnographic approaches including participant observation, in-depth interviews, unstructured and open-ended interviews and others tools and techniques by adopting emic and etic approaches. This study analyzed how and what extend the Lyngams culture differ from other communities especially in terms of Khasis and Garos and their overall influences, similarities and differences. This is an exploratory inquiry, used qualitative methods to generate data based on the live experiences, views, attitudes of Lyngams existing customs and behaviour. To perform this study a total number of 125 respondents were chosen from the study area based on convenience sampling which is sort out by the help of community leaders and experienced persons with differing backgrounds and histories including the cultural dynamics of the Lyngam. The interview was carried out with different ages of people including gender among the community people. To accomplish this study an unstructured interview schedule was administered with them. A thematic method was employed after a systematic transcription of narratives.

\section{Discussion}

This paper investigates the inherent position of Lyngams way of life - how they lead traditional and modern life in keeping with other communities. It also examines their origin, histories and existing trend of cultural dynamics. It is believed that based on racial and cultural ground the Lyngams are a distinct ethnic minority. But the thing is that the distinctiveness of Lyngam culture is the consequences of diffusion of diverse culture. It is mixed up of Khasis and Gros cultural etiquettes. The Lyngams major social and cultural construction and constituents derive from the spectrum of Khasi and Garo culture. But it has not been officially or institutionally acknowledged. There are some oral tradition prevailed in Lyngam society that the source and origin of Lyngam culture is emerged from Khasi and Garo tradition. Now the Lyngam custom, ritual, and belief are reformed through Christianization. Traditional ritual is being changed by outer influences. Social, political, and economic institution bring forth the overall change of the Lyngam contemporary culture including Christianity and traditional religiosity. Global village concept is not now excluded from Lyngam cultural practices. Major findings of Lyngams obtained from narratives are presented here briefly. Themes focussed for analyses were struggle for redefining respondents' cultural phenomena, traits, trends, and its implications, and diverse use with experiences, economic and social stigma, and influences of matrilineal dominance.

\section{Structural and Demographic Analysis of Lyngams}

The word 'Lyngam' means 'cool'. The Lyngam people are calm in nature. The matrilineal systems of the Lyngam and the Khasi are quite similar. The Lyngams as culturally intermediate between the Khasis and Garos. In appearance they resemble to the Garos with their flat noses, small eyes and strong body structures. In Bangladesh a few family (not more than ten villages) of Lyngams reside in Kalmakanda Upazila in the north-eastern district of Netrokona. In Bangladesh, the Khasi community lives in the five districts that is to say: Habiganj, Moulvibazar, Nertokona, Sylhet and Sunamganj. The Khasi who resides in Habiganj and Moulvibazar are called them the Wars. The Khasi who abides in Sylhet are called them the Synteng (Jaintia) or Jaintia Khasi. In this country a considerable number of Khasi are settled in the district of Moulvibazar. The Khasi who inhabits at Tahirpur (Sunamganj) and Kalmakanda (Netrokona) are called them the Lyngams. It is estimated that the Lyngams population is 3100 only. They have been living in harmony with Khasi and Garo culture over a long time. An idea is introduced in Lyngam society that they inter-marry the Garos and they are the descendants of the Khasi. The population distribution of the Lyngams is shown in Table 1.

Table 1. population distribution of the Lyngams

\begin{tabular}{|c|c|c|}
\hline Village & Families & Population \\
\hline Boro Mongara & 80 & 310 \\
\hline Choto Mongora & 85 & 301 \\
\hline Mohadeo & NA & NA \\
\hline Patlaban & 150 & 455 \\
\hline Kandapara & 40 & 122 \\
\hline Sannyasipara & 110 & 423 \\
\hline Jagirpara & 50 & 231 \\
\hline Bangkona & 40 & 225 \\
\hline Panchgaon & 175 & 685 \\
\hline Nongyllai & 30 & 148 \\
\hline Dippur & 40 & 210 \\
\hline Total & 700 & 3100 \\
\hline
\end{tabular}

Source: Survey of Baruakona Catholic Mission, 2012 
In addition, five Lyngam families live in Rajai village in Tahirpur Thana of Sunamganj district and in a few Khasi pinjis (villages). The Baruakona Catholic Mission on enumerated the Lyngams in Kalmakanda Thana at 3100 in 2012. A good number of Lyngams who used to live in Tahirpur migrated to India during the partition in 1947. The War Khasi constitutes the majority of the 12280 Khasis as to the 1991 census in Bangladesh. In Indian State of Meghalaya, about 1,000,000 Lyngams are native to the Khasi and Jainta hills. A good number of Lyngams live with other Khasi tribes in the Brahmaputra valley and the Surma Valley in the northern and southern part of the state. The real numbers of Lyngams are difficult to say because they are enumerated with other Khasi tribes. However, why the Lyngams living in Kalmakanda are cut off from other Khasis in the northeast is still unknown.

\section{Customs and Habits}

Literature reveals that up to 1950 Lyngams made minimum use of clothing, women had little more than a loin cloth. The little loin cloth was resembled the Garo dress. The Lyngam harvest paddy in September- November and celebrate feast in every village. While the paddy field is prepared, then the first phase of paddy cultivation is performed collectively with friends and relatives. This kind of community cultivation process does not need to pay cash to them. At best the organizer has to arrange a food festival for them with liquors. In Lyngam term it is called Yiarab (help of friends in work). Same system is lingered in harvesting period also. In this way, they are like Khasis.Lyngams made rice-beer called 'kiad'; rice is need for kiad industry and the rest is eaten. Many Lyngams have no thought for the morrow and once the feasting is over, there is not much paddy left. The Lyngams not thought of lean months till the next harvest season. Even sometimes they face paddy shortage for sawing. In this process, they are like Garos. In earlier times, the Lyngams would go to a long trip/journey with some eggs to avoid risk of journey, while they cross a river or multiple intersections of roads or rivers; they break an egg for success of their trips and same thing they would do to the next step up to the destination. To see the black cat, empty jar was the symptom of trouble full journey. They believe these practises till today. But youngster Lyngams do not practice it anymore due to the influence of scientific knowledge. The Lyngams' birth, death, and naming ritual prevail as their respective culture and heritage. Today's Lyangams look smart and well dressed, generous and like to share what they have, men are progressive, advance compared with women. It may be due to outer influence of plain land people.

\section{Language}

The Lyngam is an Austro-Asiatic language of northeast
India; once it is listed as dialect of Khasi. In current literature, the Lyngam has been classified as a distinct language which shares a common custom with standard Khasi. The Lyngams speaks their own language even though they can understand and speak the Garo language as well. They speak in a dialect that is the mixture of Khasi and Garo. But the root of the word is Khasi and very little are known about the origin of the Lyngams dialect. For long it was considered to be a dialect of Garo. Garierson demonstrates that it has no correlation with any language of the Tibeto-Burman family. Scholar Grierson (1928) estimated half a century ago, there were only about 2000 people who spoke Lyngam. Now it is admitted by the scholars that Lyngam is a peculiar dialect of Khasi, which has been influenced by Garo (Grierson, 1928). But some Lyngam sources report that their language is nearly 70 per cent identical to the Khasi language. Though, there is a controversy about it. They do not have an alphabet. In writing, they use the Roman alphabet.

\section{Marital System of Lyngams}

Matrilineal system, mother right, and other similar terms refer in general to the organisation of a social group centred on the mother in a given social group. It affects descent, kinship, inheritance, authority, marriage and individual and social privileges. Social inheritance is determined by descent from the mother, descent is matrilineal. The name of the individual is taken from the mother of the family. The Lyngam community has 25 to 30 sub clans, each with separate last names or surnames. Some of these names are: Dkhar, Nongmin, Nonglandu, Nongbri, Rengcheng, Nongsarab, Nongtingir, Nongmausor, Nongura, Hahshah, Nongdaju, Sohlomar, Langam, Maram, Rongrim, Nougchyrkon etc. They are more related to the relatives of the mother. Inheritance is determined by one's relationship to the mother of the family. It is a central factor in any matrilineal system. But sometimes it may be held by the uncle. In fact one's right to inheritance is determined by the kind and degree of relationship to one's mother.

Succession in regard to office, rank, and chieftaincy are determined by one's relationship to the mother. The holding and exercise of power and authority in the family is related to mother. This social system is called matriarchate. This is more common that the Khasis, Garos and the Lyngams are matrilineate in nature. It is protected in relation to mother. In matrilineal society, marriage system is endogamous within a given social group, in others marriage is exogamous, and it is within the tribe but always outside the clan. Sometime brother of the mother is powerful than husband. The Lyngams are a fusion of Khasi and Garo, practice a form of mother-right closely resembling that of the Khasis. Men can exercise power on his acquired property and also sometime over the property of his wife and even appoint a member of his clan. The Lyngams follow matrilineal system. However, it is not strictly applied; boys can receive some share in the family property. The family is ruled by the mother and 
children adopt the name of the mother's 'Jait' or clan [14].

\section{Marriage}

The Lyngams, like the Khasis, do not marry within the "Kur" or clan. This is strictly forbidden. They intermarry to the Garos. However, a Lyngam never marries within the groups, sub clan or community, where he or she belongs. In keeping with the matrilineal custom, a male usually moves to the female house after marriage. On the day of wedding they sacrifice a pig and two fowls at the house of the bridegroom. Another nuptial practice among the Lyngam is that the bride's family gives the bride groom's family around Tk. 20 to 30 thousand. However, this is not the dowry or bride price practice of the Bengalis; it is observed as a symbol of respect among the Lyngams. In Lyngam society, there is no custom of reciprocity of dowry. Divorce is allowed in Lyngam society; during a divorce, the money which is given to the bridegroom's family that have to give back to the bride's family. Nowadays, mixed marriage between the Lyngam and the Garos in Kalmakanda is very common. The tradition and custom of the Lyngams marriage sometimes seems as the composition of Khasi and Garo marriage, though it has an unique character.

Although the Lyngam are associate with the Khasi community, there is a confusion among the people of Kalmakanda about their identity due to their alienation from the larger part of the Khasi community. Being unaware of their anthropological history, some members of the Lyngam community even believe themselves to be part of the Garo community. However, they do not think that they belong to the two large Abeng or Atong groups of the Garo community; they mistakenly think that they are a separate group among the Garos. Except some specific attributes the Lyngam community is almost identical to those of the Garo community. That is why researcher considers Lyngam as part of the Garo community. But 'Lyngams are not Garo', says Ms. Preetilota Nongura, assistant headmistress of Baruakona School (personal communication with respondent).

\section{Polygamy}

Some historian and anthropologists hold that polygamy was practiced by the Lyngam [12]. It was practiced among the Khasi too, which was borrowed from Khasi to Lyngams. Today the practice of polygamy among Khasi as well as Lyngam is not very widespread as before due to the process of Christianization for over a hundred years. The practice of polygamy in some areas of Khasi hills are found in a special form which was made to fit into Khasi social structure [11]. The first wife had a privileged position and the others were considered as secondary wife. That is seen among the Lyngam also and they did not live in a single household with second wife. The Khasi practices polygamy in a new shape to the context of their social and family structure that could be called polygyny [3]. Nowadays pure polygamy and polygyny system are not found among the Khasi, Garo and Lyngam in Kalmakanda of Bangladesh. The Lyngam polygyny differs greatly from the polygyny of other societies in terms of its operation and structure. It also varies in the incentive to its practice. Among the Garo the practice of polygyny usually depends on a man's economic capability. But among the Lyngams, it appears rather to depend on his whim. In Lyngam areas now Christian missionaries discourage the polygyny system. Child birth system among the Kalmakanda's Lyngam is marked by the sacrifice of a fowl. There is no special ceremony to mark the occasion of the naming of a child.

\section{Head-hunting}

Among the Lyngams in Rashir clan Head-hunting was performed till the year 1850 [6]. The Rashir clan of the Lyngams seems to have been head-hunters till recently. There have a sign that some of them were also cannibalistic. In fact the Khasi used to call them 'bam briew' that means man-eaters. Head-hunting among the Rashir clan seems to have been part of a ritual. It was the part of ritual of them. The man of the clan hunted for anyone's head and brought it to be buried with the bones. It would be exciting to examine the impact of such ritual head-hunting and burial practices. If that was not possible at least the blood of the victim was brought and buried withbones for salvation of the spirit of deceased person and prosperous of the clan. But urbanisation, industrialization and Christianization have died out head-hunting ritual among the Rsshir clan, that speed of spirit of head-hunting ritual disseminated different parts of northeast India as well as Kalmakanda of Bangladesh. Now instead of head-hunting, animal hunting prevail for deceased person as well as their livelihood. In addition, somebody believed that head-hunting ritual was not true, only to protect themselves from the other community. They pretend themselves as a wild community, to give threats to other community to survive with their prestige (source: personal communication from informant).

The Lyngam burial used to be an exclusive function. In earlier times if any stranger comes during the time of burial he will be killed and buried along with deceased. They believe that the strangers' spirit will belong to the devil and the deceased departed soul keep in peace. If more heads are offered to him, he would make the clan prosper more. If the required number of heads were not buried with the dead body, they feared that they would be impoverished and various misfortunes would befall them. The status of the clan would also be tarnished. Such practices are infrequently reported now. In fact, there are very few cases of murder among the Lynams. The Lyngam also had funeral ceremonies called Lynneng that they celebrated in remembrance of the dead. Kaior Chieng is another Lyngam ritual observed for the dead. In this ritual people sing a song while wandering with a bone of the deceased person. The song is sung to call for the peace of the departed soul. A flute played in a mournful tune accompanies the song. As the Lyngams have become Christians, this and other rituals are no longer in practice. 
The Lyngams now bury dead bodies according to Christian practice.

\section{Economic Life}

The Lyngams used to be a swidener and semi-nomadic tribe like many others, living on forest products and cultivating rice and other product like maize, chillies, bananas, etc. But gradually they settled down in permanent villages and they keep domestic animals such as chickens, cows and pigs. In fact the practice of Jhum cultivation has led to very extensive deforestation and consequent ecological imbalance and soil erosion. Now the increase of population, in-migration and shortage of farming land the Lyngams have given up their most traditional farming system Jhum (slash and burn) and have taken up agriculture and private services in order to earn a living. Most of the Lyngams in Kalmakanda earn a living from agriculture. Their landholding system is divided into public and private lands. These are owned by syiems (petty chiefs), clans, villages and individuals. These categories of land are controlled by king, priest and villagers. The output and dispute of land is distributed and mitigated by respective village Sirdars or Mantris. Today the numbers of landless Lyngams are more due to the impact of industrialization, urbanization along with land grabbers. As a result landless Lyngams cross the Indian border to sell vegetables, fish and purchase sugar, salt, dress material and special cloths made by Indian indigenous people. They then sell these items in Bangladesh. Recently, some of them are working in coal mine in India and also do business of coal and become well of day by day (personal communication). Some Lyngams also work in other people's fields and quite a significant number of them almost 40 percent work in church related services. The Lyngam community wants to improve their economic condition. According to the survey of Baruakona Catholic Mission, Lyngam possess 1200 acres of land in Netrokona District. Many Lyngam sell their labour through different jobs to earn a living. The Nongmin of Barukona claimed that local Bengalis have grabbed most of their land by lending them money at a high interest rate and taking away their land as collection on their debt (personal communication). The land of this area is naturally less fertile. The extraction of coal that occurred near the area ruined much of its original fertility. The arable land that remains is frequently eroded during the monsoon when water from the hills flushes the area. There is no electricity in Kalmakanda and communication is poor. The major transports are carts, bicycles, motorbikes and boats due to unpaved roads. However, the Lyngams are trying to improve their condition by migrating to the city and taking up jobs in shops, offices, homes, diplomat mission and beauty parlor, says Father Wilson Jambil of Baruakona Catholic Mission (personal communication with respondents).

\section{Education}

The Baptist Christian missionaries, together with converting the Lyngams to Christianity, emphasised their educational needs. The first Christian missionary to settle in the Khasi Hills of Cherrapunjii was Rev. Alexander B. Lish in 1832. He established three primary schools. Later, in 1841 the Welsh Presbyterian Church sent Rev. Thomas Jones to start the Roman script in their schools, discarding the Bengali script. He published the first Khasi elementary textbook along with a few other books, including translations of parts of the Bible. It could be mentioned that the above institution and person have inspired and reformed the seed of modern education. However, missionary efforts on education and education materials were mostly very rudimentary, only fit for village school teachers or village pastors to spread Christianity and glorify the West. As the time went on, the Lyngams realized the needs for higher education. That essence of education spilled over on Lyngam areas and a few of them get opportunity to study higher education. Researcher found in his study in January 2013 only 230 students studying in high schools in ten Lyngam inhabited villages in Kalmakanda. Among them 130 were boys and 100 were girls and twenty five boys and thirteen girls studied in college. Eleven boys and three girls studied in a university. Twenty one boys and eleven girls had obtained a bachelor degree, ten boys had obtained their masters degree and one girl had done so. Christian Missionaries played a vital role in spreading education among the Lyngams. Most of the children study in Missionary schools. Among the Lyngam poverty is the main cause of poor education and also lack of sufficient educational material, infrastructure, and institution. Though, nowadays Lyngam leaders practise on education for the integrated progress of their community. There is another interesting phenomenon that except the general education system, the vocational, technical and religious education system prevails among them. It is extremely important for the Lyngam specialized education, in fields such as health, law and justice, engineering and technology and natural science and environment. It is important to realize that for small groups of ethnic communities. It is almost impossible to arrange support for such specialized education. State support is essential to provide the starter-push.

\section{Religious Beliefs}

Today most of the Lyngams have embraced Christianity and belong to different Christian Churches. The original religious beliefs of the Lyngams are only their ancestral religion [6]. Most of the tribal people of northeast India the Lyngams are animistic in religious beliefs, practices and forms of worship, especially ancestral worship. They believe in the existence of spirits and their presence in forest, rivers, etc. The Lyngams believe in a 'primeval ancestress' from whom they are said to have descended. The welfare of the 
clan and tribe, a cow is sacrificed to this 'primeval ancestress'. Along with it a gourd of rice-beer, some leaves and the jaw-bone of the animal sacrificed are hung up in the house. Lyngams are animistic and traditional religion has many rituals and deities. Kynnia is one of the Lyngam religious rituals in which animals are slaughtered and dedicated to their deity for recovery from ailments. Another ancient Lyngam deity is called Blee, one funeral ceremony is called Lynneng celebrated for remembrance of the dead.

The Lyngams have a very vague notion of sin. Only that which hurt another is considered as sin. But their oldest form of practice like head-hunting are not considered as hurting others and hence not sinful. Though, it is not exist in Kalmakanda now. Animal sacrifice is introduced not only during the birth of a child but also for the God of the forest, illness, and cultivation etc. The idea of life after death and the spirits of dead have a connection with the living. They are benevolent or malevolent towards the living. The Lyngams believe in a sacred mountain, departed souls of them abode there like heaven.

Tribal life all over the world presents us with strange, impressive, touching and traditional practices. The Lyngams tradition is not out of it. The dead body of the Lyngam is kept in bamboo hut where they used to live, near the fire place or above it is supported by three bamboo poles almost year round. The closest to the dead person keep eyes not to gather flies and insect on it. Once the dead body becomes de-hydrated and turned to a skeleton and remained in a hut with psycho-physical hazards for a year or so. During the period of waiting family gather sufficient resources in kind to give 'banquet' to all in village for emancipation of spirit of the dead. In this burial celebration relatives of the dead person arrange week-long food and drinks with liquors. It is usually a sabbatical week free from all moral restraints. This kind of funeral practice has been controlled by British administration in the last century. But some pagan families still follow this custom, though rarely and clandestinely. The corpse may also be rolled up in a mat and tied to a tree and the same procedure is then followed with regard to the burial of the bones. If any corpse is not buried following the Lyngam customs due to the complexities of state codes, later year after the bones are dug out and cremated as customary celebration.

\section{Social and Political Organizations}

Although the Lyngam are connected with the Khasi community, there is a puzzlement among the people of Kalmakana about their identity due to their isolation from the larger part of the Khasi community. Being unaware of their anthropological history, some members of the Lyngam community even believe themselves to be part of the Garo community. The Lyngams share similar food habits, family systems and kinship affairs with Khasis and Garos. Resembling the Garos, the Lyngams are matrilineal like Khasis also, their community has twenty to thirty sub-clans, each with separate surnames and they never marry a member of their own group or sub-clan. The Lyngams kinship ties are very strong. Besides this, a Lyngam is very helpful to other Lyngam due to their similar character. Modernization and over all development concepts count distort their familial unity too much. In Lyngam community it is observed that most of the Lyngams embraced the Christianity with different sects of Christianity - Presbyterian, Church of Gods, and Baptist Christianity and so on. As the Lyngams have become Christian, their traditional and ancestral ritual is no longer used too much. Even modern educated young person would not go very frequent in Churches. Though, the Fathers of Church in different sects of Christianity play a role among the Lyngams social life. If any disputes arise among them surrounding familial issues such as land, domestic animal, children, sports, marriage, farming, meeting, leadership, debates of local leadership or any other issues, then the Sardars and his selected Morols and Murobbis along with local Panchayet initially solve it. Normally most of the problems are mitigated locally and usually they don't go to the court in town. In these activities, Christian missions' Fathers and pastors are employed as block (area) chairmen to surveillance the Lyngam villages. They also give moral ethical support to the Sardars, Morols, Murobbis and Panchayet system. Their rural arbitrary and judicial system is very authoritative. Besides this Lyngams villagers make some clubs and associations to develop socio-economic position. These institutions provide loan and credit to their respective members of the Lyngams to update their health, hygiene and sanitation system. They also get grant from local and central government with different NGOs and Mission. The Lyngams are very peaceful; they are not directly related to national politics. But they participate in national referendum to choose their favourite parliamentarian and local government representatives.

\section{Myths and Legends}

The Lyngams have some myths and legends. The Syntengs have a myth surrounding cats. The Khasis and the Garos believe in the tiger as the embodiment of the human spirit. The Lyngams believe that each man has their own entity and inner power that is called tiger - the part of the spirit of man himself. The tiger is his other self. Each man possesses it that protects him, or takes revenge up on him or his behalf or punishes him as his conduct demands. The myth of Lyngams that is a man's spirit takes the form of a tiger, it becomes a tiger. Sometime it becomes a snake. When the spirit is not present the man concerned becomes drowsy. If someone hurts or attacks the incarnated tiger, the embodied spirit of tiger-man is died automatically. The attachment of the spirit of tiger-man aware the man what is happening around, who are his enemies. When the man dies, his tiger comes to claim the body. The Lyngams also believe that the dead man sometime transform into a cat. There are many legends prevail in Lyngam society. The spirit of tiger-man is inherent 
in different form and shape among the Lyngams. It is closely related to lycanthropy, namely, the belief that a man is actually transformed into an animal such as tiger, leopard, hyena etc. Such myths are found in Europe, China, Africa etc. [8]. In northeast India among several other tribes have similar stories of 'tiger-man'.

The Chakasang Nagas believe that each man has a tiger of his own. Similar belief has in Sema Nagas community. Hutton told in his writing of the Sema Nagas that the soul may be visualized of as a shadow, and that it is separable from the body, and may occupy the body of a leopard or a tiger during life. In addition to its habitation the human body is leading a sort of dual existence. Another parable was introduced that one man of a group has fallen under a fallen tree and one his leg crushed. He lay in jungle for eight days. A tourist recovered him and admitted him in hospital with accompanied his brother. But he died soon and his body was kept in a hut. While his brother went to have his meal, some boys came to take his place. Within those few minutes of change over, the wounded man's leg disappeared. Immediately they all said that his tiger spirit has come and taken away his leg!

\section{Conclusions}

The findings discussed here for exploring a distinct mode about the Lyngams way of life that is accumulated through the spectrum of Khasi and Garo culture. In this write up the analysis of Lyngam culture is highlighted on their societal form, customs and habits, language, marital systems, property ownership, economic life, education, belief and ritual, myths and legends along social and political organization. All these issues are influenced by outer influences. The Lyngams encounter many social challenges in redefining their identity including diverse issues of culture. All these traits and attributes of Lyngams culture are enriched through the integration of different elements of dominant culture. But the Lyngams ethnically assumed that their culture is distinct from others. On the other hand, different scholars and researcher found that the Lyngams are not pure Khasi and not pure Garo. At best they may be considered as partially blending, but distinct character, of
Khasi and Garocommunity. The Lyngams physical structures and linguistic peculiarities show that they are an Austro-Asiatic Mon-Khmer speaking people in the region.

\section{REFERENCES}

[1] Bareh, H.;The history and culture of the Khasi people. Guwahti: Spectrum Publications; 1985

[2] Bhattacharjee, J. B.; The Garos and the English, 1765-1874. New Delhi: Radiant Publishers; 1978

[3] Cooper, J.; The Garo of Bangladesh: A forest people's struggle to survive. Ethnic and Racial Studies, 1992; 15(1), 85-101.

[4] Dalton, E. T.; Descriptive ethnology of Bengal. Calcutta: Office of the superintendent of government printing; 1872.

[5] Grierson, G. A.;Linguistic survey of India. Calcutta. Vol. 2.; 1928.

[6] Gurdon, P. R.,The Native Races of India: The Khasis. New Delhi: Cosme Publication; 1975 (First published in 1907).

[7] Gurdon, P. R. T.;The Khasis. London: Macmillan and Company Limited, 1914.

[8] Hutton, J. H.;The Sema Nagas.London, Macmillan and Company Limited, 1948.

[9] Lyngdoh, H.; Toward a new curriculum for the Khasi people (Doctoral dissertation, Pacific University), 1949.

[10] Mathur, P. R. G.; The Khasi of Meghalaya: A Study in Tribalism and Religion. New Delhi: Cosmo, 1979.

[11] Nakane, C.; Garo and Khasi: A Comparative Study in Matrilineal Systems, Paris, Water de Gruyter GmbH \& Company; p. 135-137; 1967.

[12] Natarajan, N.;The missionary among the Khasis. New Delhi: Sterling Publishers; 1977.

[13] Playfair, A.; The Garos. Guwahati: United publishers; 1909.

[14] Rivers, W. H.; Mother right in: Encyclopaedia of Religion and Ethics, ed. James Hustings, Edinburgh, vol. 8; 1915.

[15] Sangma, M. S.; History and Culture of the Garos. New Delhi: Books Today; 1981. 